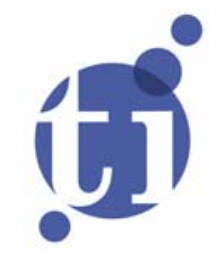

\title{
The Pleasures and Pains of Self-Employment: A Panel Data Analysis of Satisfaction with Life, Work, and Leisure
}

Peter van der Zwan ${ }^{1,2}$

Jolanda Hessels ${ }^{1,2}$

Cornelius A. Rietveld ${ }^{1,2}$

' Erasmus School of Economics, Erasmus University Rotterdam, the Netherlands, Erasmus Happiness Economics Research Organisation (EHERO);

2 Tinbergen Institute, the Netherlands. 
Tinbergen Institute is the graduate school and research institute in economics of Erasmus University Rotterdam, the University of Amsterdam and VU University Amsterdam.

More TI discussion papers can be downloaded at http://www.tinbergen.nl

Tinbergen Institute has two locations:

Tinbergen Institute Amsterdam

Gustav Mahlerplein 117

1082 MS Amsterdam

The Netherlands

Tel.: +31(0)205251600

Tinbergen Institute Rotterdam

Burg. Oudlaan 50

3062 PA Rotterdam

The Netherlands

Tel.: +31(0)10 4088900

Fax: $+31(0) 104089031$

Duisenberg school of finance is a collaboration of the Dutch financial sector and universities, with the ambition to support innovative research and offer top quality academic education in core areas of finance.

DSF research papers can be downloaded at: http://www.dsf.nl/

Duisenberg school of finance

Gustav Mahlerplein 117

1082 MS Amsterdam

The Netherlands

Tel.: +31(0)20 5258579 


\title{
The pleasures and pains of self-employment: A panel data analysis of satisfaction with life, work, and leisure
}

\author{
Peter van der Zwan ${ }^{\mathrm{a}, \mathrm{b}, \mathrm{c}}$, Jolanda Hessels ${ }^{\mathrm{a}, \mathrm{b}, \mathrm{c}}$, Cornelius A. Rietveld ${ }^{\mathrm{a}, \mathrm{d}}$ \\ a Erasmus School of Economics, Erasmus University Rotterdam, \\ P.O. Box 1738, 3000 DR, Rotterdam, the Netherlands \\ ${ }^{\mathrm{b}}$ Erasmus Happiness Economics Research Organisation (EHERO), Erasmus University \\ Rotterdam \\ c Tinbergen Institute \\ ${ }^{\mathrm{d}}$ Erasmus University Rotterdam Institute for Behavior and Biology (EURIBEB), Erasmus \\ University Rotterdam
}

\begin{abstract}
:
We investigate how a transition from paid employment to self-employment in the labor market influences life satisfaction. Furthermore, we consider the dynamics of work and leisure satisfaction because the balance between work and leisure is an important element of life satisfaction. Fixed-effects regressions using German Socio-Economic Panel data (19842012) reveal that switching to self-employment benefits life and work satisfaction. The effects on life satisfaction are weak and temporary, but they are pronounced and relatively persistent for work satisfaction. However, the gain in work satisfaction is outweighed by a decrease in leisure satisfaction, thus placing work-life balance under severe pressure.
\end{abstract}

Corresponding author: Peter van der Zwan, Erasmus School of Economics, Erasmus University Rotterdam, P.O. Box 1738, 3000 DR, Rotterdam, the Netherlands, vanderzwan@ese.eur.nl, tel.: +31104081727, fax: +31104089141.

Keywords: Self-employment, Entrepreneurship, Life satisfaction, Work satisfaction, Worklife balance

JEL codes: I31, J24, J28, J31, L26

Acknowledgement: The data used in this publication were made available to us by the German Socio-Economic Panel Study (SOEP) at the German Institute for Economic Research (DIW), Berlin. We would like to thank Martin Carree, Marcus Dejardin and Roy Thurik for their useful suggestions. 


\section{Introduction}

The number of people who choose self-employment over paid employment as a career has steadily increased in industrialized countries since the late 1990s (Fairlie and Meyer 2000; Carrasco and Ejrnæs 2012). Currently, self-employed individuals represent a nonnegligible share of the total labor force at approximately $16 \%$ in the European Union (Eurostat 2015), and they are responsible for a large portion of employment and job creation (De Wit and De Kok 2014). Many governments attempt to stimulate self-employment (Gilbert, Audretsch, and McDougall 2004; European Commission 2013) because of its positive link with economic resilience (Audretsch and Keilbach 2004; Carree and Thurik 2010; Koellinger and Thurik 2012).

Self-employment is associated with job characteristics such as a high level of autonomy (Hundley 2001), flexibility (Parasuraman and Simmers 2001), and rewarding work content (Benz and Frey 2008; Millán, Hessels, Thurik, and Aguado 2013). Such job characteristics translate into higher levels of work satisfaction for the self-employed compared with the paid employed (Blanchflower and Oswald 1998; Blanchflower 2000; Hundley 2001; Benz and Frey 2004, 2008; Bianchi 2012; Millán, Hessels, Thurik, and Aguado 2013), despite the fact that the earnings of the self-employed are on average lower, more skewed, and more volatile than those of the paid employed (Hamilton 2000). Much less is known, however, about how such job characteristics affect the non-working life of the self-employed. As a result of their autonomy and flexibility, the self-employed are less constrained by traditional office hours and may perform their work tasks at a time and location that they consider convenient. This flexibility can make it easier for self-employed individuals to meet their family demands and positively affect their non-working life in general as well as strengthen their work-life balance (Loscocco 1997; Parasuraman and Simmers 2001). 
However, the boundaries between the working and private lives of the self-employed may be less clear because of their more flexible office hours and freedom in choosing their work location. These conditions can make it more difficult for them to detach from work during their off-time. Furthermore, the greater job involvement of the self-employed in terms of longer working hours relative to those of the paid employed (Ajayi-Obe and Parker 2005; Hyytinen and Ruuskanen 2007) leaves self-employed individuals with less (quality) time for non-work activities, such as engaging in leisure activities. Consequently, self-employed individuals may have difficulties balancing their working life with their non-working life. Given these two contrasting views on the influence of self-employment on non-working life, it is unclear how self-employment affects individuals' work-life balance and welfare in general.

This paper aims to investigate the consequences of switching from paid employment to self-employment for one's welfare in general and for the balance between one's working and non-working activities. To this end, we focus on how the switch to self-employment affects one's satisfaction with life (as a proxy for general welfare) and one's welfare in two main components of the work-life balance: satisfaction with work and satisfaction with leisure. Work-life balance is typically defined as the ability to cope with work-related and non-workrelated demands (Siegel, Post, Brockner, Fishman, and Garden 2005). As the first component of work-life balance, work satisfaction is considered important to one's overall well-being or welfare (Judge and Watanabe 1993; Erdogan, Bauer, Truxillo, and Mansfield 2012). Although many non-work-related dimensions may affect work-life balance (e.g., children, family, dwelling, sports), we regard leisure as an overarching non-work component that one must balance against work. The choice of work and leisure is driven by the theory of time allocation, which postulates that income-producing activities (i.e., work) and leisure are the two components that determine individuals' levels of utility and well-being (Becker 1965; 
Lévesque and Minniti 2006). Leisure satisfaction, as the second component of work-life balance, has largely been neglected in prior research on self-employment. Earlier studies have, for example, investigated leisure satisfaction in relation to workers versus non-workers (Van Praag, Frijters, and Ferrer-i-Carbonell 2003) and to particular subgroups, such as older people (Ragheb and Griffith 1982) and students (Misra and McKean 2000). Considering leisure satisfaction along with work satisfaction helps to provide a more nuanced view of how a transition to self-employment affects the work-life balance and, subsequently, life satisfaction.

The topic of life satisfaction has occupied a much more prominent place in the economics literature in recent years (Di Tella and MacCulloch 2006; Frey and Stutzer 2002), although the topic is rooted in psychology (Kahneman, Diener, and Schwarz 2003). This attention to life satisfaction is not surprising, as "there is probably no other goal in life that commands such a high degree of consensus" (Frey and Stutzer 2010, p. vii). One of its merits is that life satisfaction is an observable proxy for utility (Frijters, Haisken-DeNew, and Shields 2004a). Moreover, a high level of life satisfaction has several benefits, for example, in terms of worker productivity levels (Oswald, Proto, and Sgroi 2015) and various other outcomes, such as performing fulfilling work, enjoying satisfying relationships, and generally enjoying good mental and physical health (Lyubomirsky, King, and Diener 2005).

The contribution of the present study to the existing economics literature is threefold. First, we address an under-researched topic: the consequences of switching to selfemployment for individual welfare. Although an extensive body of research has examined the determinants of entry into self-employment (Fairlie and Meyer 2000; Yuengert 1995), little is known about how a switch to self-employment influences life satisfaction and work-life balance at the individual level. It is well known that becoming unemployed has severe consequences for one's level of subjective well-being (Luechinger, Meier, and Stutzer 2010; 
Winkelmann and Winkelmann 1998). In addition, the impact of losing one's job is persistent because unemployed individuals find it difficult to adapt to their unemployment status with regard to individual welfare (Clark, Diener, Georgellis, and Lucas 2008). We depart from this broad distinction between being employed and unemployed and focus on the occupational choice between self-employment and paid employment (Blanchflower and Oswald 1998). In particular, we change our focus from transitions out of the labor market to transitions within the labor market between paid employment and self-employment. Transitions within the labor market can help individuals to attain better job opportunities (Postel-Vinay and Robin 2002), achieve career and personal objectives, and realize personal fulfillment. These transitions within the labor market are important for individual worker mobility and may prevent unemployment and its severely negative effects on life satisfaction. At the national level, labor mobility is crucial for improving competitiveness because, for example, it facilitates the economy's adaptation to rapid changes in supply and demand and may enhance technological progress through information externalities (Cooper 2001).

The second contribution is that the current study delves deeper into the relationship between self-employment and life satisfaction. The few studies that have focused on the link between self-employment and life satisfaction have not thoroughly investigated the mechanisms through which self-employment influences life satisfaction (Blanchflower and Oswald 1998; Andersson 2008; Stephan and Roesler 2010; Binder and Coad 2013; SalinasJiménez, Artès, and Salinas-Jiménez 2013). As noted above, the mere fact that the selfemployed are more satisfied with their work does not necessarily mean that their life satisfaction is also greater (Binder and Coad 2013). Analyzing how switching to selfemployment affects work-life balance not only helps to answer the question of whether selfemployment influences life satisfaction but also aims to explain why this effect occurs. 
The third contribution refers to the longitudinal approach, which allows us to understand the persistence of the effects of switching from paid employment to selfemployment on life, work, and leisure satisfaction. Our approach is novel in the research area of satisfaction and self-employment because of the current predominance of cross-sectional studies. For example, the existing research fails to address whether increases in work satisfaction after entering self-employment are persistent or only temporary. According to "adaptation theory" (Frey and Stutzer 2002), individuals adjust to prior levels of satisfaction after some change has occurred, such as marrying (Clark, Diener, Georgellis, and Lucas 2008) or winning the lottery (Kuhn, Kooreman, Soetevent, and Kapteyn 2011). Similarly, individuals who switch from paid employment to self-employment and who subsequently experience an increase in work satisfaction may adjust to their prior levels of work satisfaction after some time. This research question is appealing and relevant in the context of adaptation theory, but a proper test has not been performed in the existing literature. The present study is the first to investigate how life, work, and leisure satisfaction evolve after an individual becomes self-employed.

Our longitudinal approach allows us to overcome some empirical challenges that are typically encountered in the existing research on the relationship between self-employment and satisfaction. First, the results from cross-sectional studies could be biased toward a oneperiod instantaneous "shock" in terms of individual satisfaction levels. For example, the positive relationship between self-employment and work satisfaction that is typically found in earlier works could result from an individual's dissatisfaction prior to switching. Our longitudinal approach departs from this instantaneous view and observes whether selfemployment, as opposed to paid employment, has some longer-lasting, persistent, benefits. This approach eliminates the possibility that a significant relationship results from dissatisfaction prior to the self-employment switch. Second, our fixed-effects (FE) estimation 
approach, rather than a cross-sectional approach, reveals how changes in self-employment status are related to changes in satisfaction within individuals while controlling for unobserved time-invariant individual characteristics. For example, (nearly) time-invariant personality characteristics (DeNeve and Cooper 1998), such as an individual's "growth need strength" (that is, the desire for autonomy and other enriched task characteristics), could influence the relationship between self-employment and satisfaction. By adopting a FE approach, we ensure that our results are not distorted by the selection of individuals with particular personality characteristics in self-employment.

In this study, we use longitudinal data from the German Socio-Economic Panel (SOEP) and follow self-employed and paid employed individuals in Germany over a total period of almost 30 years (from 1984 to 2012). The following results are obtained. Switching from paid employment to self-employment leads to a small short-term increase in life satisfaction, whereas a much stronger and longer-term increase in work satisfaction can be observed at least five years after the switch to self-employment has occurred. By contrast, the results for leisure satisfaction are strikingly negative. That is, one's dissatisfaction with leisure outweighs one's satisfaction with work, and the pattern becomes more pronounced as the duration of self-employment increases. Such a clear pattern for leisure satisfaction cannot be observed for individuals who switch from self-employment to paid employment. Hence, a switch to self-employment has positive influences on one's work satisfaction for several years but clearly exerts pressure on one's work-life balance. This result provides an explanation for why increases in life satisfaction are not persistent for those switching to selfemployment. In sum, our findings confirm the importance of investigating the relationship between self-employment and life and work satisfaction in a longitudinal context. That is, we find a positive relationship between self-employment and life satisfaction, but only directly after switching to self-employment. Additionally, although increases in work satisfaction are 
more pronounced after switching to self-employment, such gains in work satisfaction tend to decrease over time. This result suggests that the higher levels of work satisfaction for the selfemployed found in prior cross-sectional studies are primarily observed in the early years after switching to self-employment. Our findings also confirm that focusing on work satisfaction alone provides a limited picture of how self-employment may influence life satisfaction. Given the persistent negative relationship between self-employment and leisure satisfaction found in the present paper, satisfaction with leisure should not be neglected in future research.

This paper is structured as follows. Section 2 provides the literature background. Section 3 describes the data and explains the empirical strategy. Descriptive statistics for the data used in the analyses are also described in this section. The empirical results are reported in Section 4, and Section 5 concludes the paper.

\section{Self-employment and satisfaction}

This section briefly elaborates on the relationships tested in our empirical section. First, we consider the influence of switching from paid employment to self-employment on worklife balance in terms of work and leisure satisfaction. Second, we focus on how the switch to self-employment is expected to influence life satisfaction.

\subsection{Self-employment and work-life balance}

Work-life balance, or work-life conflict, refers to the mutual interference of pressures as the result of work-related and non-work-related responsibilities (Siegel, Post, Brockner, Fishman, and Garden 2005). In other words, work-life conflict is a specific “... form of interrole conflict whereby the role demands of one domain interfere with the demands of a role in another domain" (Boswell and Olson-Buchanan 2007, p. 596). Individuals with a good 
work-life balance are able to combine their working and non-working life in a satisfactory manner, entailing high levels of work satisfaction and leisure satisfaction.

Consistent with earlier cross-sectional research that finds higher levels of work satisfaction for the self-employed compared with paid employees (Blanchflower and Oswald 1998; Blanchflower 2000; Hundley 2001; Benz and Frey 2004, 2008; Bianchi 2012; Millán, Hessels, Thurik, and Aguado 2013), we expect a positive relationship between selfemployment and work satisfaction. The self-employed are expected to be more satisfied with their work because they enjoy more "procedural utility" from operating independently in markets and do not report to a boss (Hamilton 2000; Hundley 2001; Benz and Frey 2008). We are, however, uncertain about the lasting impact of this relationship in view of adaptation theory (Frey and Stutzer 2002), as explained above, and one of the aims of our analysis is thus to unravel the degree of persistence of this relationship.

As already emphasized in the introduction, the relationship between self-employment and leisure satisfaction - and, hence, work-life balance - is more difficult to predict. Gains in work satisfaction must be weighed against possible losses in terms of satisfaction with nonwork activities such as leisure because of the greater attachment to and involvement in a selfemployed individual's job. Alternatively, the autonomy and flexibility of self-employment may make it easier for individuals to meet the demands of their private life and may enhance leisure satisfaction. Because this study is the first to associate self-employment with leisure satisfaction, we abstain from formulating an expectation about the direction and permanent nature of their relationship.

\subsection{Self-employment and life satisfaction}

Although many insights about what makes individuals or societies satisfied with life have been offered (Dolan, Peasgood, and White 2008), the role of occupational choice, 
particularly self-employment, is underrepresented in the research, as reflected by the sparse studies of self-employment mentioned in the literature reviews by Dolan, Peasgood, and White (2008) and Erdogan, Bauer, Truxillo, and Mansfield (2012). We investigate how a switch to self-employment influences life satisfaction while also considering the implications of such a switch for work and leisure satisfaction. Our choice is largely motivated by the twolayer model (Van Praag, Frijters, and Ferrer-i-Carbonell 2003) and the "bottom-up approach" (Erdogan, Bauer, Truxillo, and Mansfield 2012) to life satisfaction, which entail that life satisfaction is a function of satisfaction with other domains in life, such as work, leisure, family, and health. What people report about their life satisfaction is then a function of their satisfaction with different life domains. Based on this two-layer model and bottom-up approach, we expect that satisfaction in the work and leisure domains - the two components of work-life balance-will affect life satisfaction.

The expected positive relationship between self-employment and work satisfaction may lead one to suspect greater life satisfaction for the self-employed, as work satisfaction is expected to affect life satisfaction positively (Parlow 2010). Similarly, leisure satisfaction is expected to positively influence life satisfaction (Van Praag, Frijters, and Ferrer-i-Carbonell 2003). However, we noted above the unanticipated influence of the self-employment switch on leisure satisfaction. Difficulty detaching from work and strong job involvement, for example, may come at the expense of leisure and, consequently, life satisfaction for the selfemployed (Hahn and Dormann 2013; Matthews, Wayne, and Ford 2014); however, greater flexibility in combining work and private demands might enhance their leisure and life satisfaction levels. Hence, providing theoretical expectations for how switching to selfemployment influences life satisfaction over time is difficult because it is unclear which 
mechanism prevails. Indeed, prior cross-sectional ${ }^{1}$ studies have only speculated about why the self-employed would be more or less satisfied with their lives and have not tested any explanations for their findings. In the present paper, we examine work-life balance-in terms of work and leisure satisfaction - to understand what happens to life satisfaction levels over time after individuals become self-employed.

\section{Data, methodology, and descriptive analysis}

Data from the German SOEP (Frick, Jenkins, Lillard, Lipps, and Wooden 2007; Wagner, Frick, and Schupp 2007) are used to investigate how self-employment relates to life satisfaction, work satisfaction, and leisure satisfaction. We use annual SOEP data from 1984, the first year of data collection, to 2012. The SOEP is administered by the German Institute for Economic Research, DIW Berlin. This longitudinal dataset is suitable for the present study because it contains information regarding individuals' self-employment status and life satisfaction, work satisfaction, and leisure satisfaction scores for each of the 29 years for which we have data. The analyses are restricted to individuals between 18 and 65 years old.

${ }^{1} \mathrm{We}$ are aware of two earlier studies that investigate how transitions from paid employment to self-employment influence one's life satisfaction scores. Andersson (2008) does not find a significant relationship between self-employment and life satisfaction in a twoperiod fixed-effects regression. A more extensive analysis is provided by Binder and Coad (2013), who investigate life satisfaction changes for self-employed and paid employed individuals using 9 waves from the British Household Panel Study dataset. These authors find that individuals who move from paid employment to self-employment (an "opportunity-based" move) experience increases in life satisfaction, whereas individuals moving from unemployment to self-employment (a "necessity-based" move) do not experience such increases. The approach in the present paper has at least two extensions to the analysis of Binder and Coad (2013). First, we incorporate the role of work-life balance to understand how life satisfaction is affected by the switch to selfemployment. Second, we consider a possible persistent influence of switching to selfemployment on life satisfaction up to five years after making the transition. We also use a longer lifespan in our analyses, comprising a period of nearly thirty years. 


\subsection{Transition within the labor market: from paid employment to self- employment}

In the SOEP, individuals report their main occupational status at the time of the survey. We distinguish between self-employed individuals - excluding farmers and individuals who help on a family firm - and individuals in paid employment (which includes blue-collar, white-collar, and civil-service workers). Self-employment is a frequently used proxy for entrepreneurship in empirical work (Parker 2009). Note that we focus on paid employed and self-employed individuals only and do not consider individuals who do not work or who seek employment.

For our study, it is essential to determine an individual's switch from paid employment to self-employment. Such a switch is identified when an individual is in paid employment at time $t-1$ and in self-employment at time $t$. Our variable switch self-employment $\left(S_{t}\right)$ takes the value 1 when this occurs and the value 0 for any time $t$ when an individual is in paid employment. Note the implicit time lag between a switch from paid employment to selfemployment and satisfaction, as the switch occurs sometime during the period between $t-1$ and $t$, with satisfaction levels obtained from time $t$. Our switch variable thus reflects the immediate influence of switching from paid employment to self-employment versus being (or remaining) in paid employment on life, work, and leisure satisfaction. The total period of self-employment can vary from under a month to one year in practice. Note that multiple switches from paid employment to self-employment are possible for the same individual within one year. Although we cannot exclude the possibility that an individual switches employment statuses multiple times during the period between $t-1$ and $t$, we believe that such frequent switching does not occur often in practice, and we therefore assume that we adequately capture employment switches. 
In addition to the immediate influence of switching to self-employment on satisfaction, we investigate the persistence of the occupational switching effect on our life, work, and leisure satisfaction measures. This approach also enables a direct test of whether any adaptation occurs after switching to self-employment in terms of returning to the pre-switch levels of satisfaction. We generate five additional variables, $S_{t+j}(j=1,2,3,4,5)$, that denote self-employment (value 1) versus paid employment (value 0 ) at times $t+1, t+2, t+3, t+4$, and $t+5$ after switching from paid employment to self-employment at time $t$. This methodology is consistent with the empirical strategy of Clark, Diener, Georgellis, and Lucas (2008). Specifically, if $S_{t+j}$ takes the value 1, then an individual has switched to self-employment at time $t$ and is still self-employed rather than being in paid employment at time $t+j$. In other words, $S_{t+j}$ denote lagged switches to self-employment while still being in self-employment at time $t+j$. Hence, the variables $S_{t+j}$ reflect individuals who have been in self-employment for 0 to 1 year $\left(S_{t}\right), 1$ to 2 years $\left(S_{t+1}\right), 2$ to 3 years $\left(S_{t+2}\right), 3$ to 4 years $\left(S_{t+3}\right), 4$ to 5 years $\left(S_{t+4}\right)$, or more than 5 years $\left(S_{t+5}\right)$. We use five years as the maximum because few individuals remain in self-employment for six years or longer after the switch.

\subsection{Transition within the labor market: from self-employment to paid employment}

In our empirical analysis, we compare individuals who switch to self-employment with those who are or remain in paid employment, as explained above. We also compare this selfemployment switch with the transition to paid employment. This comparison benchmarks the switch to self-employment against the labor market switch in the other direction and is necessary for the interpretation of the results from the first analysis. In this manner, we are able to distinguish a pure switching effect from a switching to self-employment effect. For this purpose, we generate the variable switch paid employment $\left(P_{t}\right)$ that takes the value 1 when an individual is in self-employment at time $t-1$ and in paid employment at time $t$ and takes the 
value 0 for any time $t$ when an individual is in self-employment. Again, we generate five additional variables, $P_{t+j}(j=1,2,3,4,5)$, that denote paid employment (value 1$)$ versus selfemployment (value 0 ) at times $t+1, t+2, t+3, t+4$, and $t+5$ after switching from selfemployment to paid employment at time $t$.

\subsection{Measures of satisfaction}

Life satisfaction is based on a self-reported measure that directly asks individuals about their general appreciation of their life. A scale from 1 to 10 is used, with 1 denoting the least satisfied individuals and 10 denoting the most satisfied individuals. This direct measurement of life satisfaction has been used frequently in recent economics literature (e.g., Clark, Diener, Georgellis, and Lucas 2008; Frijters, Haisken-DeNew, and Shields 2004a, 2004b; Luechinger, Meier, and Stutzer 2010).

We measure satisfaction with the two specific life domains - work and leisure - in an equivalent manner; hence, these measures represent proxies for derived utility from work and leisure. The two satisfaction measures are comparable in terms of phrasing and measurement with our life satisfaction variable, which benefits the coherency of our research set-up and the interpretation of the results. Such single-item satisfaction measures for the work domain (Borjas 1979; Clark 1997; Sousa-Poza and Sousa-Poza 2000; Lange 2012) and the leisure domain (Van Praag, Frijters, and Ferrer-i-Carbonell 2003; Demoussis and Giannakopoulos 2008) have been used previously in the economics literature.

Specifically, the respondents assess their overall life, work, and leisure satisfaction on a scale from 1 (completely dissatisfied) to 10 (completely satisfied). The following questions are asked: "All things considered, how satisfied are you with your life?" for life satisfaction, "All things considered, how satisfied are you with your work?" for work satisfaction, and “All things considered, how satisfied are you with your leisure?" for leisure satisfaction. 
While the original scales in the SOEP range from 0 to 10 , we decided to merge the two lowest categories because of the relatively low number of zero values for the satisfaction variables.

\subsection{Summary statistics}

The graphs in Figure 1 compare levels of life, work, and leisure satisfaction between individuals who switch from paid employment to self-employment (value 1 for $S_{t}$ ) and individuals who do not switch (value 0 for $S_{t}$ ). The benefits of switching are also depicted for the longer term ( $t+1$ to $t+5)$; each graph shows $95 \%$ confidence intervals, which are based on simple $t$-tests for satisfaction differences between switchers (value 1) and non-switchers (value 0). Clearly, switching to self-employment does not have significant benefits in terms of life satisfaction. Furthermore, we note that individuals who switch to self-employment have significantly higher work satisfaction levels than individuals in paid employment for all

time periods. Finally, leisure satisfaction is significantly negatively related to switching to self-employment, again for all time periods. These results could be attributed to the act of switching rather than to the newly attained self-employment status. Hence, we also show the "gains" or "losses" in life, work, and leisure satisfaction when people switch from selfemployment to paid employment (the $P_{t+j}$ variables) in Figure 1. Again, no benefits are found for life satisfaction, the benefits for work satisfaction are significant in the short term only, and the losses in terms of leisure satisfaction are significantly smaller in an absolute sense than for those who switch to self-employment.

Our long time horizon of almost thirty years is necessary to draw reliable conclusions regarding the influence of self-employment on satisfaction, given the relatively small number of individuals who switch from paid employment to self-employment. For example, 34,629 individuals are included in our regressions with life satisfaction as the dependent variable, and these individuals experience 1,455 switches from paid employment to self-employment 
in total. Additionally, 1,203 opposite switches from self-employment to paid employment are observed. Given that multiple switches for an individual are rarely recorded, approximately $8 \%$ of individuals experience such a switch within the labor market.

\subsection{Estimation strategy}

We perform linear fixed-effects (FE) regressions to determine the relationship between switching to self-employment $\left(S_{t+j}, j=0, \ldots, 5\right.$, are the independent variables $)$ and life, work, and leisure satisfaction (the dependent variables). The time-varying control variables are listed below. The FE results show how changes in self-employment status are related to changes in satisfaction within individuals by controlling for unobserved, time-invariant individual characteristics. Standard errors robust to heteroskedasticity are calculated. To interpret our results in an unbiased manner, we add the $P_{t+j}(j=0, \ldots, 5)$ variables, which denote switches from self-employment to paid employment, to the model formulation.

Concerns regarding multicollinearity among the $S_{t+j}$ and $P_{t+j}$ variables may arise. We investigated the corresponding Spearman correlation coefficients and variance inflation factors (VIFs) in a model with all $S_{t+j}$ and $P_{t+j}$ variables included. The correlations are below 0.05 in all cases, and all VIF values are below 1 . Hence, there are no concerns regarding multicollinearity (Hill and Adkins 2001). Additionally, for our control variables (for a description of these variables, see below), the correlations and VIF values do not lead to multicollinearity concerns.

The dependent variables in our analyses are ordered variables, and an ordered logit or probit model would therefore be more suitable to respect the ordinal nature of these variables. Our cardinal interpretation and, hence, the use of linear FE regressions have been favored by numerous scholars (e.g., Di Tella, MacCulloch, and Oswald 2001). In practice, the results from research designs that assume cardinality or ordinality show few differences (Ferrer-i- 
Carbonell and Frijters 2004). The advantage of our linear regression models is that the interpretation of coefficients is straightforward because they reflect an absolute increase or decrease in satisfaction on the 10-point scales. In addition, FE equivalents in the ordinal case are difficult to implement (Greene 2004). We show the results of a recently implemented consistent FE ordered logit estimator as a robustness check in Section 4.

\subsection{Control variables}

We base this list of individual-level control variables on Dolan, Peasgood, and White (2008), who provide a summary of the most relevant variables associated with life satisfaction. Given that studies have also included these determining factors to explain work and leisure satisfaction, we draw on the same set of control variables for our work and leisure regressions. A number of variables mentioned by Dolan, Peasgood, and White (2008) cannot be considered in our research framework. On some occasions (such as the contexts of commuting, caring for others, or trust), the SOEP dataset limits us in the availability of a certain variable for 29 consecutive years. Naturally, unemployment is not included in our analyses because our analysis is restricted to paid employed and self-employed workers.

Regarding the individual characteristics, we include educational attainment, which refers to the sum of years of schooling and years of occupational training (generated by the SOEP) and is a continuous variable from 7 to $18 .^{2}$ Marital status is also included in the list of control variables. We distinguish between married people; a category consisting of divorced, separated, and widowed people; and a category of people who have never been married (reference category in regressions).

${ }^{2}$ Years of schooling: no degree $=7$ years, lower degree $=9$ years, intermediary schooling $=10$ years, degree from a professional college $=12$ years, higher education degree $=13$ years. Years of occupational training: apprenticeship $=1.5$ years, technical schools (incl. health $)=2$ years, civil servant apprenticeship $=1.5$ years, higher technical college $=3$ years, university degree $=5$ years. 
Furthermore, we include the number of children in the household ${ }^{3}$, gross hourly earnings (log transformed) in euros per hour, the number of weekly working hours (log transformed), and the weekly number of hours devoted to leisure and hobbies (again in logs). ${ }^{4}$ Gross hourly earnings are defined by dividing annual earnings in euros by annual hours worked. The bottom percentile of the earnings distribution is not considered because of some unrealistically low values, and zero values are not included because of our focus on workers only.

Year dummies are also included in all regressions. Because we employ FE regressions, these year dummies capture time-specific influences on satisfaction and individual (linear) age effects. Hence, age is not included as a determinant of satisfaction. Importantly, our FE regressions control for unobserved, time-invariant individual characteristics such as an individual's personality (DeNeve and Cooper 1998), religious conviction, or ethnicity, and exclude gender as a control variable.

\section{Results}

Table 1 shows the FE results for the entire sample of individuals between 18 and 65 years old. The results are displayed for life satisfaction (column 1), work satisfaction (column 2), and leisure satisfaction (column 3). The results for the $S_{t}$ variable show that switching from paid employment to self-employment is significantly positively related to life satisfaction and work satisfaction directly after experiencing the switch. The result for work

\footnotetext{
${ }^{3}$ If more than 5 children are in the household, the value 5 is assigned to these observations.

${ }^{4}$ Note that satisfaction with work (one of our dependent variables) also depends on the number of hours devoted to work and that satisfaction with leisure (also a dependent variable) depends on the number of hours devoted to leisure. The results of the other independent and control variables in these regressions should thus be interpreted conditional on an important input of both satisfaction measures, which is the amount of time spent in work and leisure. Hence, the two satisfaction measures do not measure satisfaction with hours worked and satisfaction with the amount of leisure, respectively.
} 
satisfaction is more pronounced than that for life satisfaction, with a coefficient for the $S_{t}$ variable that is almost five times as large. In other words, immediate benefits for life satisfaction and work satisfaction arise from switching to self-employment from paid employment, but the benefits for life satisfaction are relatively small, given the 0.071 influence on a 10-point scale and the significance of this coefficient at only $10 \%$.

Interestingly, individuals who switch to self-employment experience a significant decline in leisure satisfaction. This finding suggests that switching to self-employment poses challenges for individuals who switch and increases the difficulty of combining working life with non-working life in terms of leisure. Clearly, leisure is threatened by individuals' engagement in self-employed work, even when we control for weekly hours devoted to leisure.

By focusing on the coefficients of the $S_{t+j}$ variables for $j=1, \ldots, 5$, we can assess the persistence of the influence of switching to self-employment on life, work, and leisure satisfaction. A few interesting observations can be made based on Table 1. First, the positive influence on life satisfaction is only temporary and not persistent, given that the coefficients of the variables $S_{t+j}(j=1, \ldots, 5)$ are not statistically significant. Second, the influence on work satisfaction is persistent, but the coefficients (apart from a satisfaction "shock" at time $t+1$ ) reveal a decreasing pattern. Nevertheless, at time $t+4$ ( 4 to 5 years after switching to selfemployment), individuals benefit from this switch in terms of significantly higher work satisfaction levels compared with individuals who remain in paid employment. Third, for leisure satisfaction, the negative coefficients remain large in an absolute sense over time. Interestingly, individuals' dissatisfaction with leisure outweighs their satisfaction with work from time $t+2$ onward. 


\subsection{From self-employment to paid employment}

We compare people who switch from paid employment to self-employment (see above) with those who make the opposite switch. For this purpose, we add the $P_{t+j}$ variables denoting switches from self-employment to paid employment to the previous regression. The corresponding results presented in Table 2 are interesting: they do not reveal a significant, persistent influence of switching to paid employment on leisure satisfaction. In addition, benefits in terms of increased work satisfaction levels arise from switching from selfemployment to paid employment. However, for $j=0,1,2$, the $P_{t+j}$ coefficients are smaller than are the $S_{t+j}$ coefficients, and they are similar in size for $j=3,4,5$. Several significant positive $P_{t+j}$ coefficients (for $j=2,3,5$ ) can be observed for life satisfaction, which indicates that switching to paid employment has more benefits for individual welfare in general than does switching to self-employment. This result could be caused by the lack of detrimental effects in terms of lower leisure satisfaction levels observed for switches to paid employment in Table 2.

\subsection{Graphical representation}

Figure 2 provides a graphical representation of the influences of switching to selfemployment $\left(S_{t+j}\right.$ coefficients from Table 2$)$ and switching to paid employment $\left(P_{t+j}\right.$ coefficients from Table 2) on life, work, and leisure satisfaction. As observed, the 95\% confidence intervals show considerable overlap for life and work satisfaction, but not for leisure satisfaction. Hence, the detrimental effect on leisure satisfaction largely distinguishes a switch to self-employment (out of paid employment) from a switch to paid employment (out of self-employment). Furthermore, the short-term benefits in terms of work satisfaction appear to be stronger for the switch to self-employment than for the switch to paid employment. 


\subsection{Inclusion of domain satisfaction variables}

To assess the importance of work and leisure satisfaction in determining one's life satisfaction level, we add these two domain satisfaction variables to the regressions with life satisfaction as the dependent variable. This approach is consistent with the two-layer model and the bottom-up approach to life satisfaction described in Section 2. We add another domain satisfaction variable to the regressions: satisfaction with one's health situation. Earlier research has demonstrated the importance of health (satisfaction) to one's life satisfaction (Diener 1984), and research has shown that relatively healthy individuals choose self-employment (Rietveld, van Kippersluis, and Thurik 2014). ${ }^{5}$

The results are shown in Table 3 for the entire sample. All domain satisfaction variables have significant, positive coefficients. Columns 1 and 2 of Table 3 reveal that satisfaction with work weighs more heavily in the determination of life satisfaction than does satisfaction with leisure. That is, Wald tests comparing the coefficients of both variables reveal that the coefficients of work satisfaction are significantly larger than are the coefficients of leisure satisfaction ( $p$-values $<0.01$ ). In addition, after adding the two domain satisfaction variables, we find that the significant influence of switching to self-employment (indicated by the coefficient of $S_{t}$ ) on life satisfaction disappears, suggesting that these two domains are responsible for the life satisfaction increase found earlier.

\subsection{Gender stratified results}

We repeat the analyses for men and women separately because women may have different reasons for switching to self-employment than men do, such as the desire to combine their work with household or childcare responsibilities (Carr 1996; Boden 1999; Carrasco and Ejrnæs 2012). The results are shown in Table 4. For men, the findings are

\footnotetext{
${ }^{5}$ Domains other than work, leisure, and health could also be included, but these domains are not available for all 29 years in our data.
} 
generally consistent with the results for the entire sample in Table 1. The results for women show a noteworthy difference: no significant, negative impact of switching to selfemployment on leisure satisfaction is observed for any of the $S_{t+j}$ variables (except for the coefficient of $S_{t+2}$, which is significant at $10 \%$ ). As a likely consequence, switching to selfemployment has some benefits in terms of life satisfaction for women, given the significant, positive coefficients of $S_{t}$ and $S_{t+1}$. Furthermore, the results for work satisfaction are more pronounced for women than they are for men. Clark (1997) explains gender differences in work satisfaction by citing women's lower expectations, and future research should test whether this mechanism also explains the results for leisure satisfaction. Another possible explanation for the finding that the disadvantages in terms of leisure satisfaction are less severe for women is that they more strongly value the flexibility between home and work that self-employment offers (Bender, Donohue, and Heywood 2005). In addition, women may suffer less from an intense focus on work because they tend to be less committed to their selfemployed ventures than men are (Parasuraman, Purohit, Godshalk, and Beutell 1996).

\subsection{Fixed-effects ordered logit regressions}

The current results are based on linear FE regressions. The main advantage of these models is that their interpretation is straightforward. In Section 3.5, we discussed the difficulties of implementing FE equivalents of ordered logit or probit models. The literature has offered some suggestions for consistent estimators for ordered logit or probit models with fixed effects. Essentially, these estimators largely involve a dichotomization of the dependent variable (Das and Van Soest 1999; Ferrer-i-Carbonell and Frijters 2004). To assess the robustness of our main results in Table 1, we apply a recently developed consistent estimator for the ordered logit model with fixed effects, as outlined by Baetschmann, Staub, and Winkelmann (2015). The results displayed in Table 5 are qualitatively similar to those in Table 1. That is, we find an instantaneous influence of switching to self-employment on life 
satisfaction, a persistent but decreasing positive influence on work satisfaction, and a large negative influence on leisure satisfaction that remains constant over time.

\section{Conclusion}

The present research focuses on individuals' mobility within the labor market and devotes specific attention to the transition from paid employment to self-employment. Using longitudinal data (1984-2012) from the SOEP, we analyze the persistence of the influence of the self-employment transition on life, work, and leisure satisfaction levels. We find that switching from paid employment to self-employment is significantly positively related to life satisfaction and work satisfaction, with the results for work satisfaction being much more pronounced than those for life satisfaction. In addition, the benefits in terms of work satisfaction are more persistent over time than those for life satisfaction. Furthermore, we find that individuals who switch to self-employment experience significant declines in their leisure satisfaction, even more than five years after switching to self-employment. The present analysis also investigates what occurs when individuals leave self-employment and switch to paid employment. The findings reveal that work satisfaction levels also tend to increase in this scenario, but the increase is weaker than that observed in the switch from paid employment to self-employment, especially in the short term. Furthermore, individuals who switch to paid employment do not experience severe declines in leisure satisfaction.

Our results show that self-employed individuals, especially self-employed men, struggle with finding a balance between work and leisure. Their satisfaction with work increases at the cost of decreased leisure satisfaction, and these effects are enduring. Hence, the pressure that self-employment places on leisure — as a result of one's responsibility for all aspects of the business, the strong job involvement associated with self-employment, and the limited boundaries between work and leisure — should not be underestimated. We certainly do 
not find evidence of positive benefits for leisure as previously been proposed in the literature (that is, that the autonomy and flexibility provided by self-employment enhances work-life balance).

Whereas individuals who switch to self-employment show a tendency for adaptation in terms of work satisfaction (in terms of decreasing coefficients), there is a clear absence of adaptation for leisure satisfaction. People who switch from paid employment to selfemployment may have difficulty adapting to their pre-switch values or coping with their newly obtained self-employed status in terms of balancing work and non-work life. One explanation for such a persistent negative impact on leisure satisfaction after switching to self-employment could be that entering self-employment and establishing a business involve extensive time, energy, and effort to evade the possible threat of business failure for several years after business entry (Evans and Leighton 1989). Additionally, leisure is valued highly by individuals, as indicated by the inclusion of leisure in time allocation models (Becker 1965; Lévesque and Minniti 2006), and difficulty may arise in coping with worse leisure circumstances resulting from life events such as a self-employment switch.

Our results help to explain why the findings of earlier studies on life satisfaction and self-employment are not as consistent as the findings on work satisfaction and selfemployment. Namely, the benefits of life satisfaction are observed only directly after the switch to self-employment; thus, when self-employed individuals are surveyed is relevant. The increase in work satisfaction for those who are self-employed is clearly outweighed by their leisure dissatisfaction, placing their work-life balance and ultimately their life satisfaction under pressure. Hence, the inclusion of leisure satisfaction in addition to work satisfaction helps to provide a more balanced picture of how the choice of self-employment affects one's work-life balance and subsequent life satisfaction. Furthermore, we find that improved work satisfaction levels tend to adjust to pre-switch levels after some time, 
suggesting a new perspective on claims that self-employment increases work satisfaction, as this effect is valid mainly in the short term. In addition, we demonstrate that the immediate benefits in terms of work satisfaction are stronger for the switch to self-employment than they are for the switch to paid employment. This result indicates that the positive effects of selfemployment on work satisfaction found in some prior studies do not simply result from switching as such. Regarding the two transitions in the labor market, we find that the detrimental effect on leisure satisfaction is what largely distinguishes a switch to selfemployment (out of paid employment) from a switch to paid employment (out of selfemployment). Thus, a switch to self-employment clearly threatens the work-life balance, but this threat is less of an issue for those who switch to paid employment.

Overall, two important considerations for future research emerge from this study. First, our results emphasize the importance of using a longitudinal approach when studying the relationship between self-employment and satisfaction. Future works should therefore apply such a longitudinal framework, preferably in countries other than Germany to assess the generalizability of our SOEP results. Second, we learned that satisfaction with leisure is an important domain to consider in future research on satisfaction and self-employment, as the most pronounced effects are found for leisure satisfaction.

Many governments have implemented policies to stimulate the choice of selfemployment (Gilbert, Audretsch, and McDougall 2004; European Commission 2013). These policies may help to stimulate economic growth, given the positive link between entrepreneurship and economic development that is found in some earlier studies. However, much less is known about the benefits of self-employment at the individual level, and our results suggest that individual-level benefits may be less clear than previous studies suggest. That is, our results offer the following nuanced view (Hanglberger and Merz 2015): few benefits in terms of life satisfaction arise, and the benefits for work satisfaction may come at 
the cost of decreased individual satisfaction in the important life domain of leisure. Hence, in addition to the lower, more skewed, and more volatile monetary compensation for selfemployed work than for work in paid employment (Hamilton 2000), self-employment is also accompanied by a persistent decline in leisure satisfaction. The question is whether people are aware of this effect when making the choice to leave paid employment and enter selfemployment. They are probably not aware, as people are likely to be driven by the attractiveness of self-employment, with its favorable job characteristics such as decisionmaking autonomy (Blanchflower, Oswald, and Stutzer 2001). Notably, the negative consequences experienced in declining leisure satisfaction could hamper entrepreneurial endeavors because of the potential for demotivation and a higher likelihood of entrepreneurial exit. Hence, people switching to self-employment should be better prepared to encounter possible difficulties in balancing work and non-work life. 


\section{References}

Ajayi-Obe, O., and S.C. Parker. 2005. "The changing nature of work among the selfemployed in the 1990s: Evidence from Britain." Journal of Labor Research 26(3):501517.

Andersson, P. 2008. "Happiness and health: Well-being among the self-employed." Journal of Socio-Economics 37(1):213-236.

Audretsch, D.B., and M. Keilbach. 2004. "Entrepreneurship capital and economic performance." Regional Studies 38(8):949-959.

Baetschmann, G., K. E. Staub, and R. Winkelmann. 2015. "Consistent estimation of the fixed effects ordered logit model." Journal of the Royal Statistical Society: Series A (Statistics in Society) 178(3):685-703.

Becker, G. 1965. "A theory of the allocation of time.” Economic Journal 75(299):493-517.

Bender, K.A., S.M. Donohue, and J.S. Heywood. 2005. "Job satisfaction and gender segregation." Oxford Economic Papers 57(3):479-496.

Benz, M., and B.S. Frey. 2004. "Being independent raises happiness at work." Swedish Economic Policy Review 11(2):95-134.

Benz, M., and B.S. Frey. 2008. "Being independent is a great thing: Subjective evaluations of self-employment and hierarchy." Economica 75(298):362-383.

Bianchi, M. 2012. "Financial development, entrepreneurship, and job satisfaction." Review of Economics and Statistics 94(1):273-286.

Binder, M., and A. Coad. 2013. "Life satisfaction and self-employment: A matching approach." Small Business Economics 40(4):1009-1033.

Blanchflower, D.G. 2000. "Self-employment in OECD countries." Labour Economics 7(5):471-505.

Blanchflower, D.G., A. Oswald, and A. Stutzer. 2001. "Latent entrepreneurship across nations." European Economic Review 45(4):680-691.

Blanchflower, D.G., and A.J. Oswald. 1998. "What makes an entrepreneur?" Journal of Labor Economics 16(1):26-60.

Boden, R.J. 1999. "Flexible working hours, family responsibilities, and female selfemployment." American Journal of Economics and Sociology 58(1):71-83.

Borjas, G. J. 1979. "Job satisfaction, wages, and unions." Journal of Human Resources 14(1):21-40.

Boswell, W. R., and J.B. Olson-Buchanan. 2007. "The use of communication technologies after hours: The role of work attitudes and work-life conflict." Journal of Management 33(4):592-610.

Carr, D. 1996. "Two paths to self-employment?: Women's and men's self-employment in the United States, 1980." Work and Occupations 23(1):26-53.

Carrasco, R., and M. Ejrnæs. 2012. "Labor market conditions and self-employment: a Denmark-Spain comparison." IZA Journal of Labor Policy 1(1):1-13.

Carree M.A., and A. R. Thurik. 2010. The impact of entrepreneurship on economic growth. In: Audretsch DB, Acs ZJ (Eds), Handbook of entrepreneurship research. Springer Verlag: Berlin, Heidelberg. 557-

Clark, A. E. 1997. "Job satisfaction and gender: why are women so happy at work?" Labour Economics 4(4):341-372.

Clark, A. E., E. Diener, Y. Georgellis, and R. E. Lucas. 2008. "Lags and leads in life satisfaction: A test of the baseline hypothesis." The Economic Journal 118(529):F222F243. 
Cooper, C., and J. Marshall. 1976. "Occupational sources of stress: a review of the literature relating to coronary heart disease and mental ill health." Journal of Occupational Psychology 49(1):1-28.

Cooper, C., and M. Smith. 1985. Job Stress and Blue Collar Work. Wiley: Chichester.

Cooper, D.P. 2001. "Innovation and reciprocal externalities: information transmission via job mobility." Journal of Economic Behavior \& Organization 45(4):403-425.

Das, M., and A. Van Soest. 1999. "A panel data model for subjective information on household income growth." Journal of Economic Behavior \& Organization 40(4):409426.

De Wit, G., and J. De Kok. 2014. "Do small businesses create more jobs? New evidence for Europe.” Small Business Economics 42(2):283-295.

Demoussis, M., and N. Giannakopoulos. 2008. "Analysis of domain satisfactions: Evidence from a panel of Greek women." The Journal of Socio-Economics 37(4):1347-1362.

DeNeve, K.M., and H. Cooper. 1998. "The happy personality: A meta-analysis of 137 personality traits and subjective well-being." Psychological Bulletin 124:197-229.

Diener, E. 1984. "Subjective well-being". Psychological Bulletin, 95:542-575

Di Tella, R., and R. MacCulloch. 2006. "Some uses of happiness data in economics." Journal of Economic Perspectives 20(1):25-46.

Di Tella, R., R. J. MacCulloch, and A. J. Oswald. 2001. "Preferences over inflation and unemployment: Evidence from surveys of happiness." American Economic Review 91(1):335-341.

Dolan, P., T. Peasgood, and M. White. 2008. "Do we really know what makes us happy? A review of the economic literature on the factors associated with subjective well-being." Journal of Economic Psychology 29(1):94-122.

Erdogan, E., T. N. Bauer, D. M. Truxillo, and L. R. Mansfield. 2012. "Whistle while you work: A review of the life satisfaction literature." Journal of Management 38(4):10381083.

European Commission. 2013. Entrepreneurship 2020 Action Plan. Reigniting the entrepreneurial spirit in Europe. Retrieved from http://eur-lex.europa.eu/LexUriServ/ LexUriServ.do?uri=COM:2012:0795:FIN:EN:PDF.

Eurostat 2015. "Labour market and Labour force survey (LFS) statistics." Retrieved from ec.europa.eu/eurostat/statistics-explained/index.php/

Labour_market_and_Labour_force_survey_\%28LFS\%29_statistics\#Self-employed.

Evans, D. S., and L. S. Leighton. $\overline{1989}$. "Some empirical aspects of entrepreneurship." American Economic Review 79(3):519-35.

Fairlie, R. W., and B. D. Meyer. 1996. "Ethnic and racial self-employment differences and possible explanations." Journal of Human Resources 31(4):757-793.

Fairlie, R. W., and B. D. Meyer. 2000. "Trends in self-employment among white and black men during the twentieth century." Journal of Human Resources 35(4):643-669.

Ferrer-i-Carbonell, A., and P. Frijters. 2004. "How important is methodology for the estimates of the determinants of happiness?" The Economic Journal 114(497):641-659.

Frey, B. S., and A. Stutzer. 2002. Happiness and Economics. Princeton, New Jersey.

Frey, B. S., and A. Stutzer. 2010. Happiness and economics: How the Economy and Institutions Affect Human Well-being. Princeton University Press.

Frick, J. R., S. P. Jenkins, D. R. Lillard, O. Lipps, and M. Wooden. 2007. "The CrossNational Equivalent File (CNEF) and its member country household panel studies." Schmollers Jahrbuch 127(4):627-654.

Frijters, P., J. P. Haisken-DeNew, and M. A. Shields. 2004a. "Investigating the patterns and determinants of life satisfaction in Germany following reunification." Journal of Human Resources 39(3):649-674. 
Frijters, P., J. P. Haisken-DeNew, and M. A. Shields, 2004b. "Money does matter! Evidence from increasing real income and life satisfaction in East Germany following reunification." American Economic Review 94(3):730-740.

Gilbert, B. A., D. B. Audretsch, and P. P. McDougall, P.P. 2004. "The emergence of entrepreneurship policy.” Small Business Economics 22(3-4):313-323.

Greene, W. 2004. "The behaviour of the maximum likelihood estimator of limited dependent variable models in the presence of fixed effects." The Econometrics Journal 7:98-119.

Hahn, V. C., and C. Dormann. 2013. "The role of partners and children for employees' psychological detachment from work and well-being." Journal of Applied Psychology 98(1):26-36.

Hamilton, B.H. 2000. "Does entrepreneurship pay? An empirical analysis of the returns to self-employment." Journal of Political Economy 108(3):604-631.

Hanglberger, D., and J. Merz. 2015. "Does self-employment really raise job satisfaction? Adaptation and anticipation effects on self-employment and general job changes." Journal for Labour Market Research Forthcoming.

Hill, R. C., and L. C. Adkins. 2001. Collinearity. In B. Baltagi (Ed.), A companion to theoretical econometrics (pp. 256-278). UK: Blackwell Publishing.

Hundley, G. 2001. "Why and when are the self-employed more satisfied with their work?" Industrial Relations 40(2):293-316.

Hyytinen, A., and O. P. Ruuskanen. 2007. "Time use of the self-employed." Kyklos 60(1):105-122.

Judge, T. A., and S. Watanabe. 1993. "Another look at the job satisfaction-life satisfaction relationship.” Journal of Applied Psychology 78(6):939-948.

Kahneman, D., E. Diener, and N. Schwarz. 2003. Well-being: The foundations of hedonic psychology. Russell Sage Foundation.

Karasek, R. A., and T. Theorell. 1990. Healthy work: Stress, productivity, and the reconstruction of working life. Basic Books: New York.

Karasek, R. A. 1979. "Job demands, job decision latitude, and mental strain: Implications for job redesign.” Administrative Science Quarterly 24(2):285-308.

Koellinger, P. D., and A. R. Thurik. 2012. "Entrepreneurship and the business cycle." Review of Economics and Statistics 94(4):1143-1156.

Kuhn, P., P. Kooreman, A. Soetevent, and A. Kapteyn. 2011. "The effects of lottery prizes on winners and their neighbors: Evidence from the Dutch Postcode Lottery." American Economic Review 101(5):2226-2247.

Lange, T. 2012. "Job satisfaction and self-employment: autonomy or personality?" Small Business Economics 38(2):165-177.

Lévesque, M., and M. Minniti. 2006. "The effect of aging on entrepreneurial behavior." Journal of Business Venturing 21(2):177-194.

Loscocco, K.A. 1997. "Work-family linkages among self-employed women and men." Journal of Vocational Behavior 50(2):204-226.

Luechinger, S., S. Meier, and A. Stutzer. 2010. "Why does unemployment hurt the employed? Evidence from the life satisfaction gap between the public and the private sector." Journal of Human Resources 45(4):998-1045.

Lyubomirsky, S., L. King, and E. Diener. 2005. "The benefits of frequent positive affect: Does happiness lead to success?" Psychological Bulletin 131(6):803-855.

Matthews, R. A., J. H. Wayne, and M. T. Ford. 2014. "A work-family conflict/subjective well-being process model: A test of competing theories of longitudinal effects." Journal of Applied Psychology, 99(6):1173-1187. 
Millán, J.M., J. Hessels, R. Thurik, and R. Aguado. 2013. "Determinants of job satisfaction: A European comparison of self-employed and paid employees." Small Business Economics 40(3):651-670.

Misra, R., and M. McKean. 2000. "College students' academic stress and its relation to their anxiety, time management and leisure satisfaction." American Journal of Health Studies $16(1): 41-51$.

Oswald, A.J., E. Proto, and D. Sgroi. 2015. "Happiness and productivity." Journal of Labor Economics Forthcoming.

Parasuraman, S., Y. S. Purohit, V. M. Godshalk, and N. J. Beutell. 1996. "Work and family variables, entrepreneurial career success, and psychological well-being." Journal of Vocational Behavior 48(3):275-300.

Parasuraman, S., and C. A. Simmers. 2001. "Type of employment, work-family conflict and well-being: A comparative study." Journal of Organizational Behavior 22(5):551-568.

Parker, S.C. 2009. The economics of entrepreneurship. Cambridge University Press: Cambridge.

Parlow, A. 2010. "The work life conflict: The relationship between job and life satisfaction." Working paper. University of Wisconsin, Milwaukee. Retrieved from http://pantherfile. uwm.edu/aparlow/www/papers/jsls.pdf

Postel-Vinay, F. and J.-M. Robin. 2002. "Equilibrium wage dispersion with worker and employer heterogeneity." Econometrica 70(6):2295-2350.

Ragheb, M.G., and C. A. Griffith. 1982. "The contribution of leisure participation and leisure satisfaction to life satisfaction of older persons." Journal of Leisure Research 14(4):295306.

Rietveld, C. A., H. Van Kippersluis, and A. R. Thurik. 2014. "Self-employment and health: Barriers or benefits?" Health Economics. DOI: 10.1002/hec.3087

Salinas-Jiménez, M. M., J. Artès, and J. Salinas-Jiménez. 2013. "How do educational attainment and occupational and wage-earner statuses affect life satisfaction? A gender perspective study." Journal of Happiness Studies 14(2):367-388.

Siegel, P. A., C. Post, J. Brockner, A. Y. Fishman, and C. Garden. 2005. "The moderating influence of procedural fairness on the relationship between work-life conflict and organizational commitment." Journal of Applied Psychology 90(1):13-24.

Sousa-Poza, A., and A. A. Sousa-Poza. 2000. "Well-being at work: a cross-national analysis of the levels and determinants of job satisfaction." The Journal of Socio-Economics 29(6):517-538.

Stephan, U., and U. Roesler. 2010. "Health of entrepreneurs versus employees in a national representative sample." Journal of Occupational and Organizational Psychology 83(3):717-738.

Theorell, T., and R. A. Karasek. 1996. "Current issues relating to psychosocial job strain and cardiovascular disease research." Journal of Occupational Health Psychology 1(1):9-26.

Van Praag, B. M., P. Frijters, and A. Ferrer-i-Carbonell. 2003. "The anatomy of subjective well-being." Journal of Economic Behavior \& Organization 51(1):29-49.

Wagner, G.G., J. R. Frick, and J. Schupp. 2007. "The German Socio-Economic Panel Study (SOEP) - Scope, evolution and enhancements." Schmollers Jahrbuch 127:139-169.

Winkelmann, L., and R. Winkelmann. 1998. "Why are the unemployed so unhappy? Evidence from panel data." Economica 65(257):1-15.

Yuengert, A. M. 1995. "Testing hypotheses of immigrant self-employment." Journal of Human Resources 30(1):194-204. 


\section{Tables}

Table 1. Coefficients of fixed-effects regressions. Dependent variables: life satisfaction, work satisfaction, leisure satisfaction. Independent variable: switching from paid employment to self-employment.

\begin{tabular}{|c|c|c|c|}
\hline & $\begin{array}{c}\text { (1) } \\
\text { Life }\end{array}$ & $\begin{array}{c}(2) \\
\text { Work }\end{array}$ & $\begin{array}{c}(3) \\
\text { Leisure }\end{array}$ \\
\hline$S_{t}$ & $\begin{array}{l}0.071^{*} \\
(0.039)\end{array}$ & $\begin{array}{l}0.335^{* * * *} \\
(0.053)\end{array}$ & $\begin{array}{l}-0.280 * * * \\
(0.057)\end{array}$ \\
\hline$S_{t+1}$ & $\begin{array}{l}0.075 \\
(0.046)\end{array}$ & $\begin{array}{l}0.428 * * * \\
(0.062)\end{array}$ & $\begin{array}{l}-0.332 * * * \\
(0.070)\end{array}$ \\
\hline$S_{t+2}$ & $\begin{array}{l}0.047 \\
(0.054)\end{array}$ & $\begin{array}{l}0.299 * * * \\
(0.068)\end{array}$ & $\begin{array}{l}-0.339 * * * \\
(0.081)\end{array}$ \\
\hline$S_{t+3}$ & $\begin{array}{l}0.019 \\
(0.058)\end{array}$ & $\begin{array}{l}0.200 * * * \\
(0.075)\end{array}$ & $\begin{array}{l}-0.396 * * * \\
(0.093)\end{array}$ \\
\hline$S_{t+4}$ & $\begin{array}{l}0.003 \\
(0.066)\end{array}$ & $\begin{array}{l}0.178 * * \\
(0.081)\end{array}$ & $\begin{array}{l}-0.411 * * * \\
(0.101)\end{array}$ \\
\hline$S_{t+5}$ & $\begin{array}{l}-0.018 \\
(0.066)\end{array}$ & $\begin{array}{l}0.131 \\
(0.087)\end{array}$ & $\begin{array}{l}-0.390 * * * \\
(0.098)\end{array}$ \\
\hline Education & $\begin{array}{l}0.002 \\
(0.007)\end{array}$ & $\begin{array}{l}0.019 * \\
(0.010)\end{array}$ & $\begin{array}{l}-0.014 \\
(0.011)\end{array}$ \\
\hline Married & $\begin{array}{l}0.092 * * * \\
(0.022)\end{array}$ & $\begin{array}{l}0.064 * * \\
(0.029)\end{array}$ & $\begin{array}{l}-0.160^{* * * *} \\
(0.030)\end{array}$ \\
\hline Widowed/divorced/separated & $\begin{array}{l}-0.087 * * * \\
(0.033)\end{array}$ & $\begin{array}{l}0.100 * * \\
(0.041)\end{array}$ & $\begin{array}{l}-0.088^{* *} \\
(0.042)\end{array}$ \\
\hline Children & $\begin{array}{l}-0.000 \\
(0.007)\end{array}$ & $\begin{array}{l}0.037 * * * \\
(0.009)\end{array}$ & $\begin{array}{l}-0.145^{* * *} \\
(0.010)\end{array}$ \\
\hline Ln(hourly earnings) & $\begin{array}{l}0.182 * * * \\
(0.011)\end{array}$ & $\begin{array}{l}0.171 * * * \\
(0.015)\end{array}$ & $\begin{array}{l}0.050 * * * \\
(0.014)\end{array}$ \\
\hline Ln(work hours) & $\begin{array}{l}0.104 * * * \\
(0.010)\end{array}$ & $\begin{array}{l}0.084 * * * \\
(0.015)\end{array}$ & $\begin{array}{l}-0.276^{* * *} \\
(0.014)\end{array}$ \\
\hline Ln(leisure hours) & $\begin{array}{l}0.043 * * * \\
(0.004)\end{array}$ & $\begin{array}{l}0.025 * * * \\
(0.005)\end{array}$ & $\begin{array}{l}0.244 * * * \\
(0.006)\end{array}$ \\
\hline Intercept & $\begin{array}{l}7.003 * * * \\
(0.101)\end{array}$ & $\begin{array}{l}6.963 * * * \\
(0.141)\end{array}$ & $\begin{array}{l}7.985 * * * \\
(0.143)\end{array}$ \\
\hline $\begin{array}{l}\text { Observations } \\
\text { R-squared (within) } \\
\text { Number of individuals }\end{array}$ & $\begin{array}{l}220,980 \\
0.023 \\
34,629\end{array}$ & $\begin{array}{l}217,060 \\
0.018 \\
34,157\end{array}$ & $\begin{array}{l}220,839 \\
0.031 \\
34,622\end{array}$ \\
\hline
\end{tabular}

Robust standard errors in parentheses. Year dummies are included. Reference category for marital status is "never married".

$* * * p$-value $\leq 0.01, * * p$-value $\leq 0.05, * p$-value $\leq 0.1$. 
Table 2. Coefficients of fixed-effects regressions. Dependent variables: life satisfaction, work satisfaction, leisure satisfaction. Independent variables: switching from paid employment to self-employment and from self-employment to paid employment.

\begin{tabular}{|c|c|c|c|}
\hline & $\begin{array}{c}(1) \\
\text { Life } \\
\end{array}$ & $\begin{array}{c}(2) \\
\text { Work } \\
\end{array}$ & $\begin{array}{c}(3) \\
\text { Leisure }\end{array}$ \\
\hline$\overline{S_{t}}$ & $\begin{array}{l}0.075^{*} \\
(0.041)\end{array}$ & $\begin{array}{l}0.375 * * * \\
(0.054)\end{array}$ & $\begin{array}{l}-0.295 * * * \\
(0.059)\end{array}$ \\
\hline$S_{t+1}$ & $\begin{array}{l}0.078^{*} \\
(0.047)\end{array}$ & $\begin{array}{l}0.462 * * * \\
(0.063)\end{array}$ & $\begin{array}{l}-0.345^{* * *} \\
(0.071)\end{array}$ \\
\hline$S_{t+2}$ & $\begin{array}{l}0.050 \\
(0.054)\end{array}$ & $\begin{array}{l}0.331^{* * *} \\
(0.069)\end{array}$ & $\begin{array}{l}-0.352 * * * \\
(0.082)\end{array}$ \\
\hline$S_{t+3}$ & $\begin{array}{l}0.022 \\
(0.058)\end{array}$ & $\begin{array}{l}0.229^{* * * *} \\
(0.076)\end{array}$ & $\begin{array}{l}-0.407 * * * \\
(0.093)\end{array}$ \\
\hline$S_{t+4}$ & $\begin{array}{l}0.006 \\
(0.067)\end{array}$ & $\begin{array}{l}0.204 * * \\
(0.082)\end{array}$ & $\begin{array}{l}-0.421 * * * \\
(0.102)\end{array}$ \\
\hline$S_{t+5}$ & $\begin{array}{l}-0.015 \\
(0.067)\end{array}$ & $\begin{array}{l}0.155^{*} \\
(0.087)\end{array}$ & $\begin{array}{l}-0.399 * * * \\
(0.098)\end{array}$ \\
\hline$P_{t}$ & $\begin{array}{l}-0.031 \\
(0.046)\end{array}$ & $\begin{array}{l}0.201 * * * \\
(0.062)\end{array}$ & $\begin{array}{l}-0.147 * * \\
(0.061)\end{array}$ \\
\hline$P_{t+1}$ & $\begin{array}{l}-0.037 \\
(0.056)\end{array}$ & $\begin{array}{l}0.186^{* *} \\
(0.074)\end{array}$ & $\begin{array}{l}0.015 \\
(0.080)\end{array}$ \\
\hline$P_{t+2}$ & $\begin{array}{l}0.118^{* *} \\
(0.058)\end{array}$ & $\begin{array}{l}0.247 * * * \\
(0.077)\end{array}$ & $\begin{array}{l}-0.098 \\
(0.091)\end{array}$ \\
\hline$P_{t+3}$ & $\begin{array}{l}0.177 * * * \\
(0.068)\end{array}$ & $\begin{array}{l}0.246 * * * \\
(0.087)\end{array}$ & $\begin{array}{l}-0.065 \\
(0.092)\end{array}$ \\
\hline$P_{t+4}$ & $\begin{array}{l}0.078 \\
(0.075)\end{array}$ & $\begin{array}{l}0.208 * * \\
(0.088)\end{array}$ & $\begin{array}{l}0.019 \\
(0.109)\end{array}$ \\
\hline$P_{t+5}$ & $\begin{array}{l}0.199 * * \\
(0.083)\end{array}$ & $\begin{array}{l}0.243 * * \\
(0.107)\end{array}$ & $\begin{array}{l}0.053 \\
(0.119)\end{array}$ \\
\hline Education & $\begin{array}{l}0.002 \\
(0.007)\end{array}$ & $\begin{array}{l}0.018^{*} \\
(0.010)\end{array}$ & $\begin{array}{l}-0.014 \\
(0.011)\end{array}$ \\
\hline Married & $\begin{array}{l}0.092 * * * \\
(0.022)\end{array}$ & $\begin{array}{l}0.063 * * \\
(0.029)\end{array}$ & $\begin{array}{l}-0.160^{* * * *} \\
(0.031)\end{array}$ \\
\hline Widowed/divorced/separated & $\begin{array}{l}-0.088^{* * *} \\
(0.033)\end{array}$ & $\begin{array}{l}0.097 * * \\
(0.041)\end{array}$ & $\begin{array}{l}-0.088^{* *} \\
(0.042)\end{array}$ \\
\hline Children & $\begin{array}{l}-0.000 \\
(0.007)\end{array}$ & $\begin{array}{l}0.036^{* * *} \\
(0.009)\end{array}$ & $\begin{array}{l}-0.145^{\text {*** }} \\
(0.010)\end{array}$ \\
\hline Ln(hourly earnings) & $\begin{array}{l}0.181^{* * *} \\
(0.011)\end{array}$ & $\begin{array}{l}0.172 * * * \\
(0.015)\end{array}$ & $\begin{array}{l}0.049 * * * \\
(0.014)\end{array}$ \\
\hline Ln(work hours) & $\begin{array}{l}0.103 * * * \\
(0.010)\end{array}$ & $\begin{array}{l}0.083^{* * *} \\
(0.015)\end{array}$ & $\begin{array}{l}-0.276^{* * *} \\
(0.014)\end{array}$ \\
\hline Ln(leisure hours) & $\begin{array}{l}0.043 * * * \\
(0.004)\end{array}$ & $\begin{array}{l}0.025^{* * *} \\
(0.005)\end{array}$ & $\begin{array}{l}0.244 * * * \\
(0.006)\end{array}$ \\
\hline Intercept & $\begin{array}{l}7.007 * * * \\
(0.101)\end{array}$ & $\begin{array}{l}6.974 * * * \\
(0.141)\end{array}$ & $\begin{array}{l}7.983 * * * \\
(0.143)\end{array}$ \\
\hline $\begin{array}{l}\text { Observations } \\
\text { R-squared (within) } \\
\text { Number of individuals } \\
\end{array}$ & $\begin{array}{l}220,980 \\
0.023 \\
34,629 \\
\end{array}$ & $\begin{array}{l}217,060 \\
0.018 \\
34,157 \\
\end{array}$ & $\begin{array}{l}220,839 \\
0.031 \\
34,622 \\
\end{array}$ \\
\hline
\end{tabular}

Robust standard errors in parentheses. Year dummies are included. Reference category for marital status is "never married". *** $p$-value $\leq 0.01, * * p$-value $\leq 0.05, * p$-value $\leq 0.1$. 
Table 3. Coefficients of fixed-effects regressions with domain satisfactions added. Dependent variables: life satisfaction, work satisfaction, leisure satisfaction.

\begin{tabular}{|c|c|c|}
\hline & $\begin{array}{c}(1) \\
\text { Life }+ \text { domain satisfactions }\end{array}$ & $\begin{array}{c}(2) \\
\text { Life }+ \text { domain satisfactions } \\
\end{array}$ \\
\hline$S_{t}$ & $\begin{array}{l}0.016 \\
(0.036)\end{array}$ & $\begin{array}{l}0.017 \\
(0.037)\end{array}$ \\
\hline$S_{t+1}$ & $\begin{array}{l}0.023 \\
(0.043)\end{array}$ & $\begin{array}{l}0.024 \\
(0.044)\end{array}$ \\
\hline$S_{t+2}$ & $\begin{array}{l}0.032 \\
(0.048)\end{array}$ & $\begin{array}{l}0.033 \\
(0.049)\end{array}$ \\
\hline$S_{t+3}$ & $\begin{array}{l}0.033 \\
(0.053)\end{array}$ & $\begin{array}{l}0.034 \\
(0.053)\end{array}$ \\
\hline$S_{t+4}$ & $\begin{array}{l}0.014 \\
(0.060)\end{array}$ & $\begin{array}{l}0.016 \\
(0.060)\end{array}$ \\
\hline$S_{t+5}$ & $\begin{array}{l}0.002 \\
(0.060)\end{array}$ & $\begin{array}{l}0.003 \\
(0.060)\end{array}$ \\
\hline$P_{t}$ & & $\begin{array}{l}-0.051 \\
(0.041)\end{array}$ \\
\hline$P_{t+1}$ & & $\begin{array}{l}-0.045 \\
(0.051)\end{array}$ \\
\hline$P_{t+2}$ & & $\begin{array}{l}0.110 * * \\
(0.052)\end{array}$ \\
\hline$P_{t+3}$ & & $\begin{array}{l}0.157 * * * \\
(0.058)\end{array}$ \\
\hline$P_{t+4}$ & & $\begin{array}{l}0.059 \\
(0.070)\end{array}$ \\
\hline$P_{t+5}$ & & $\begin{array}{l}0.165 * * \\
(0.074)\end{array}$ \\
\hline Education & $\begin{array}{l}-0.001 \\
(0.007)\end{array}$ & $\begin{array}{l}-0.001 \\
(0.007)\end{array}$ \\
\hline Married & $\begin{array}{l}0.089 * * * \\
(0.019)\end{array}$ & $\begin{array}{l}0.088 * * * \\
(0.019)\end{array}$ \\
\hline Widowed/divorced/separated & $\begin{array}{l}-0.113^{* * *} \\
(0.029)\end{array}$ & $\begin{array}{l}-0.113^{* * *} \\
(0.029)\end{array}$ \\
\hline Children & $\begin{array}{l}0.005 \\
(0.006)\end{array}$ & $\begin{array}{l}0.005 \\
(0.006)\end{array}$ \\
\hline Ln(hourly earnings) & $\begin{array}{l}0.145 * * * \\
(0.010)\end{array}$ & $\begin{array}{l}0.144 * * * \\
(0.010)\end{array}$ \\
\hline Ln(work hours) & $\begin{array}{l}0.110 * * * \\
(0.010)\end{array}$ & $\begin{array}{l}0.110 * * * \\
(0.010)\end{array}$ \\
\hline Ln(leisure hours) & $\begin{array}{l}0.009 * * \\
(0.004)\end{array}$ & $\begin{array}{l}0.009 * * \\
(0.004)\end{array}$ \\
\hline Work satisfaction & $\begin{array}{l}0.158 * * * \\
(0.002)\end{array}$ & $\begin{array}{l}0.158 * * * \\
(0.002)\end{array}$ \\
\hline Leisure satisfaction & $\begin{array}{l}0.097 * * * \\
(0.002)\end{array}$ & $\begin{array}{l}0.097 * * * \\
(0.002)\end{array}$ \\
\hline Health satisfaction & $\begin{array}{l}0.176 * * * \\
(0.003)\end{array}$ & $\begin{array}{l}0.176^{* * *} \\
(0.003)\end{array}$ \\
\hline Intercept & $\begin{array}{l}3.735^{* * *} \\
(0.094)\end{array}$ & $\begin{array}{l}3.738 * * * \\
(0.094)\end{array}$ \\
\hline $\begin{array}{l}\text { Observations } \\
\text { R-squared (within) } \\
\text { Number of individuals }\end{array}$ & $\begin{array}{l}216,353 \\
0.167 \\
34,135 \\
\end{array}$ & $\begin{array}{l}216,353 \\
0.167 \\
34,135 \\
\end{array}$ \\
\hline
\end{tabular}

Robust standard errors in parentheses. Year dummies are included. Reference category for marital status is "never married". *** $p$-value $\leq 0.01, * * p$-value $\leq 0.05, * p$-value $\leq 0.1$. 
Table 4. Coefficients of fixed-effects regressions for men and women. Dependent variables: life satisfaction, work satisfaction, leisure satisfaction. Independent variable: switching from paid employment to self-employment.

\begin{tabular}{|c|c|c|c|c|c|c|}
\hline & \multicolumn{3}{|c|}{ Men } & \multicolumn{3}{|c|}{ Women } \\
\hline & (1) & $(2)$ & (3) & (4) & (5) & (6) \\
\hline & Life & Work & Leisure & Life & Work & Leisure \\
\hline \multirow[t]{2}{*}{$S_{t}$} & 0.029 & $0.288 * * *$ & $-0.406 * * *$ & $0.148 * *$ & $0.424 * * *$ & -0.048 \\
\hline & $(0.049)$ & $(0.066)$ & $(0.072)$ & $(0.065)$ & $(0.089)$ & $(0.092)$ \\
\hline \multirow[t]{2}{*}{$S_{t+1}$} & 0.040 & $0.367 * * *$ & $-0.470 * * *$ & $0.143 *$ & $0.550 * * *$ & -0.028 \\
\hline & $(0.056)$ & $(0.073)$ & $(0.089)$ & $(0.080)$ & $(0.113)$ & $(0.110)$ \\
\hline \multirow[t]{2}{*}{$S_{t+2}$} & 0.026 & $0.214 * * *$ & $-0.374 * * *$ & 0.098 & $0.501 * * *$ & $-0.266^{*}$ \\
\hline & $(0.062)$ & $(0.081)$ & $(0.098)$ & $(0.106)$ & $(0.121)$ & $(0.142)$ \\
\hline \multirow[t]{2}{*}{$S_{t+3}$} & -0.035 & $0.148^{*}$ & $-0.516 * * *$ & 0.162 & $0.337 * *$ & -0.077 \\
\hline & $(0.069)$ & $(0.090)$ & $(0.108)$ & $(0.102)$ & $(0.134)$ & $(0.182)$ \\
\hline \multirow[t]{2}{*}{$S_{t+4}$} & 0.029 & 0.124 & $-0.516 * * *$ & -0.077 & $0.296^{*}$ & -0.143 \\
\hline & $(0.078)$ & (0.094) & $(0.126)$ & $(0.128)$ & $(0.159)$ & (0.164) \\
\hline \multirow[t]{2}{*}{$S_{t+5}$} & -0.036 & 0.062 & $-0.444 * * *$ & 0.018 & $0.301^{*}$ & -0.248 \\
\hline & $(0.076)$ & $(0.098)$ & $(0.111)$ & $(0.137)$ & $(0.179)$ & $(0.201)$ \\
\hline \multirow[t]{2}{*}{ Education } & $-0.022 * *$ & -0.002 & $-0.024 *$ & $0.034 * * *$ & $0.043 * * *$ & 0.009 \\
\hline & $(0.010)$ & $(0.013)$ & $(0.014)$ & $(0.012)$ & $(0.016)$ & $(0.016)$ \\
\hline \multirow[t]{2}{*}{ Married } & $0.094 * * *$ & 0.031 & $-0.132 * * *$ & $0.078 * *$ & $0.081 *$ & $-0.181 * * *$ \\
\hline & $(0.029)$ & $(0.038)$ & $(0.041)$ & $(0.034)$ & $(0.045)$ & $(0.045)$ \\
\hline \multirow[t]{2}{*}{ Widowed/divorced/separat. } & $-0.179 * * *$ & 0.072 & -0.072 & -0.004 & $0.117 *$ & -0.086 \\
\hline & $(0.045)$ & $(0.055)$ & $(0.057)$ & $(0.048)$ & $(0.060)$ & $(0.062)$ \\
\hline \multirow[t]{2}{*}{ Children } & -0.005 & 0.019 & $-0.088 * * *$ & -0.007 & $0.051 * * *$ & $-0.229 * * *$ \\
\hline & $(0.009)$ & $(0.012)$ & $(0.013)$ & $(0.012)$ & $(0.015)$ & $(0.017)$ \\
\hline \multirow[t]{2}{*}{ Ln(hourly earnings) } & $0.235 * * *$ & $0.263 * * *$ & $0.049 * *$ & $0.133 * * *$ & $0.099 * * *$ & 0.021 \\
\hline & $(0.016)$ & $(0.022)$ & $(0.021)$ & $(0.015)$ & $(0.021)$ & $(0.020)$ \\
\hline \multirow[t]{2}{*}{ Ln(work hours) } & $0.150 * * *$ & $0.190 * * *$ & $-0.379 * * *$ & $0.072 * * *$ & $0.031^{*}$ & $-0.248 * * *$ \\
\hline & $(0.017)$ & $(0.024)$ & $(0.023)$ & $(0.013)$ & $(0.018)$ & $(0.018)$ \\
\hline \multirow[t]{2}{*}{ Ln(leisure hours) } & $0.040 * * *$ & $0.028 * * *$ & $0.222 * * *$ & $0.047 * * *$ & $0.021 * *$ & $0.271 * * *$ \\
\hline & $(0.005)$ & $(0.007)$ & $(0.008)$ & $(0.007)$ & $(0.009)$ & $(0.009)$ \\
\hline \multirow[t]{2}{*}{ Intercept } & $6.974 * * *$ & $6.566^{* * *}$ & $8.562 * * *$ & $6.876^{* * *}$ & $7.130 * * *$ & $7.535 * * *$ \\
\hline & $(0.136)$ & $(0.192)$ & $(0.193)$ & $(0.158)$ & $(0.218)$ & $(0.217)$ \\
\hline Observations & 122,771 & 121,164 & 122,710 & 98,209 & 95,896 & 98,129 \\
\hline R-squared (within) & 0.026 & 0.021 & 0.031 & 0.021 & 0.016 & 0.034 \\
\hline Number of individuals & 18,418 & 18,228 & 18,411 & 16,211 & 15,929 & 16,211 \\
\hline
\end{tabular}

Robust standard errors in parentheses. Year dummies are included. Reference category for marital status is "never married".

$* * * p$-value $\leq 0.01, * * p$-value $\leq 0.05, * p$-value $\leq 0.1$. 
Table 5. Coefficients of fixed-effects ordered logit regressions. Dependent variables: life satisfaction, work satisfaction, leisure satisfaction. Independent variable: switching from paid employment to self-employment.

\begin{tabular}{|c|c|c|c|}
\hline & $\begin{array}{l}(1) \\
\text { Life }\end{array}$ & $\begin{array}{c}(2) \\
\text { Work }\end{array}$ & $\begin{array}{c}(3) \\
\text { Leisure }\end{array}$ \\
\hline$S_{t}$ & $\begin{array}{l}0.109 * \\
(0.064)\end{array}$ & $\begin{array}{l}0.424 * * * \\
(0.065)\end{array}$ & $\begin{array}{l}-0.292 * * * \\
(0.059)\end{array}$ \\
\hline$S_{t+1}$ & $\begin{array}{l}0.116 \\
(0.076)\end{array}$ & $\begin{array}{l}0.522 * * * \\
(0.075)\end{array}$ & $\begin{array}{l}-0.327 * * * \\
(0.072)\end{array}$ \\
\hline$S_{t+2}$ & $\begin{array}{l}0.068 \\
(0.088)\end{array}$ & $\begin{array}{l}0.400 \text { *** } \\
(0.086)\end{array}$ & $\begin{array}{l}-0.337 * * * \\
(0.083)\end{array}$ \\
\hline$S_{t+3}$ & $\begin{array}{l}0.043 \\
(0.094)\end{array}$ & $\begin{array}{l}0.274 * * * \\
(0.093)\end{array}$ & $\begin{array}{l}-0.382 * * * \\
(0.096)\end{array}$ \\
\hline$S_{t+4}$ & $\begin{array}{l}0.027 \\
(0.111)\end{array}$ & $\begin{array}{l}0.243 * * * \\
(0.103)\end{array}$ & $\begin{array}{l}-0.383^{* * *} \\
(0.106)\end{array}$ \\
\hline$S_{t+5}$ & $\begin{array}{l}-0.022 \\
(0.111)\end{array}$ & $\begin{array}{l}0.177 * * \\
(0.109)\end{array}$ & $\begin{array}{l}-0.406^{* * *} \\
(0.098)\end{array}$ \\
\hline Education & $\begin{array}{l}0.001 \\
(0.013)\end{array}$ & $\begin{array}{l}-0.015 \\
(0.012)\end{array}$ & $\begin{array}{l}-0.019 \\
(0.012)\end{array}$ \\
\hline Married & $\begin{array}{l}0.147 * * * \\
(0.038)\end{array}$ & $\begin{array}{l}0.063^{*} \\
(0.036)\end{array}$ & $\begin{array}{l}-0.193 * * * \\
(0.035)\end{array}$ \\
\hline Widowed/divorced/separated & $\begin{array}{l}-0.064 \\
(0.052)\end{array}$ & $\begin{array}{l}0.114 * * \\
(0.049)\end{array}$ & $\begin{array}{l}-0.118^{* *} \\
(0.047)\end{array}$ \\
\hline Children & $\begin{array}{l}-0.005 \\
(0.012)\end{array}$ & $\begin{array}{l}0.042 * * * \\
(0.012)\end{array}$ & $\begin{array}{l}-0.167^{* * * *} \\
(0.011)\end{array}$ \\
\hline Ln(hourly earnings) & $\begin{array}{l}0.278 * * * \\
(0.017)\end{array}$ & $\begin{array}{l}0.095 * * * \\
(0.017)\end{array}$ & $\begin{array}{l}0.055^{* * *} \\
(0.016)\end{array}$ \\
\hline Ln(work hours) & $\begin{array}{l}0.154 * * * \\
(0.016)\end{array}$ & $\begin{array}{l}-0.114^{* * *} \\
(0.016)\end{array}$ & $\begin{array}{l}-0.308^{* * *} \\
(0.016)\end{array}$ \\
\hline Ln(leisure hours) & $\begin{array}{l}0.064 * * * \\
(0.007)\end{array}$ & $\begin{array}{l}0.033 * * * \\
(0.006)\end{array}$ & $\begin{array}{l}0.263 * * * \\
(0.007)\end{array}$ \\
\hline Observations & 220,980 & 217,060 & 220,839 \\
\hline Pseudo R-squared & 0.02 & 0.02 & 0.02 \\
\hline Number of individuals & 34,629 & 34,157 & 34,622 \\
\hline
\end{tabular}

Robust standard errors in parentheses. Year dummies are included. Reference category for marital status is "never married".

$* * * p$-value $\leq 0.01, * * p$-value $\leq 0.05, * p$-value $\leq 0.1$. 


\section{Figures}

Figure 1. Summary statistics. Differences in satisfaction levels between movers into self-employment and paid employment, and nonmovers. The shaded areas represent the $95 \%$ Confidence Intervals.

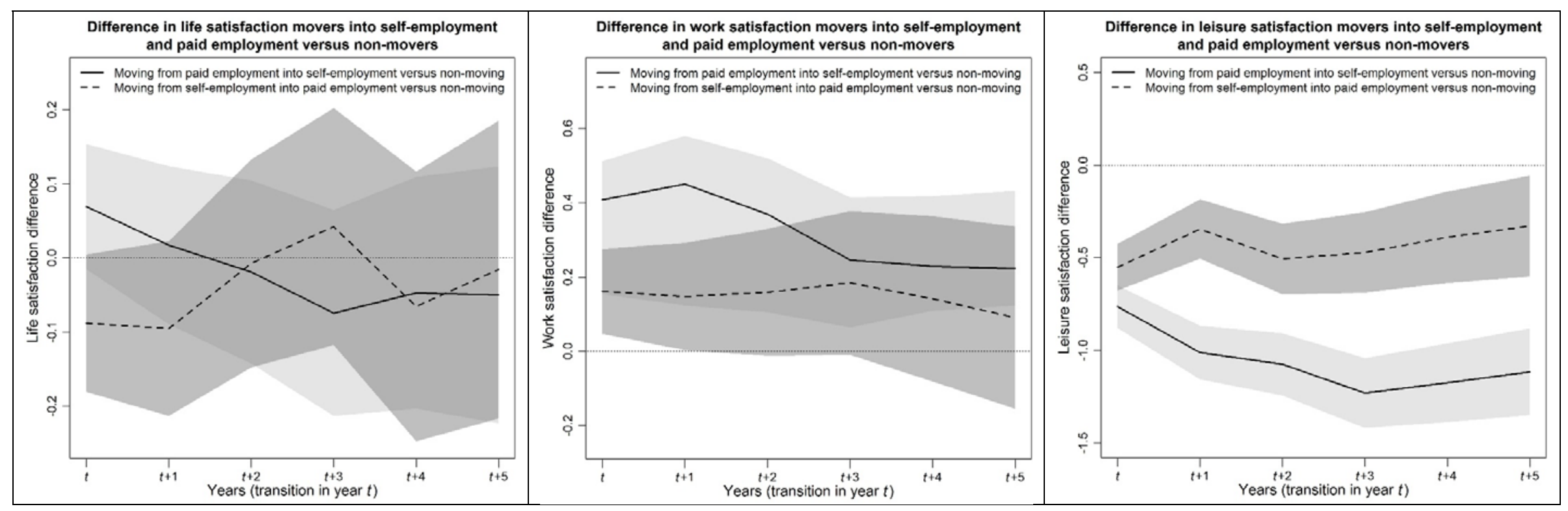


Figure 2. FE regression coefficients for moving into self-employment and paid employment (graphical representation Table 2), versus non-moving. The shaded areas represent the $95 \%$ Confidence Intervals.

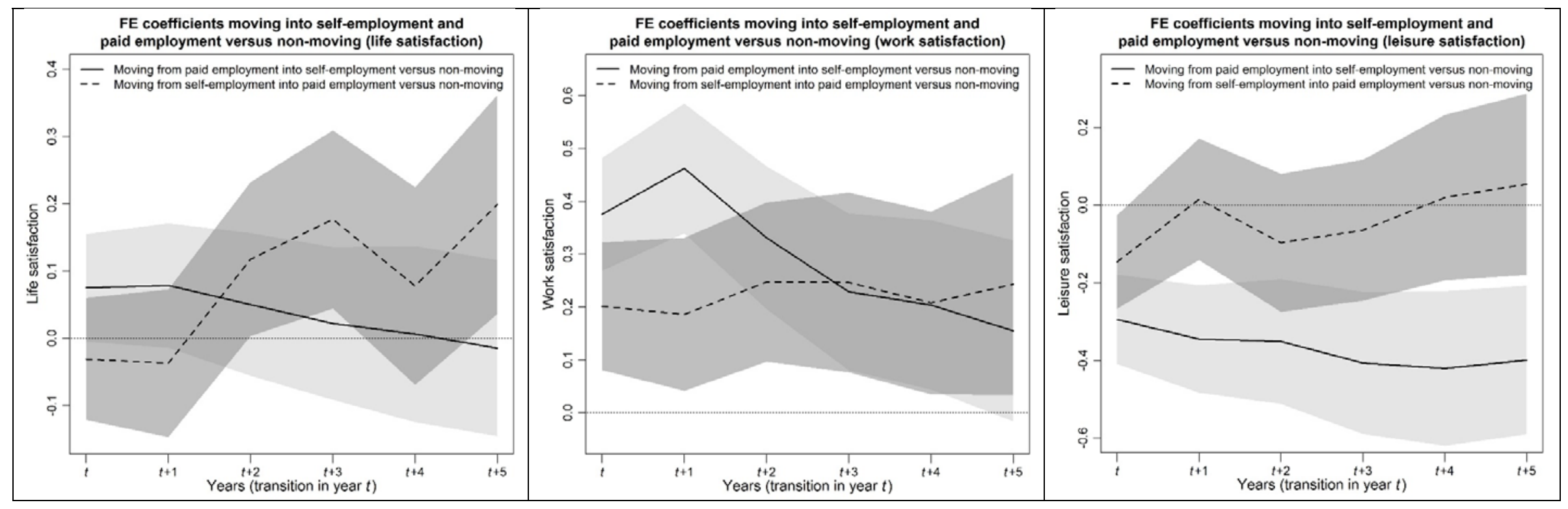

